Ks. Grzegorz Jaśkiewicz

UPJP II, Kraków

DOI: http://dx.doi.org/10.12775/BPTh.2013.013

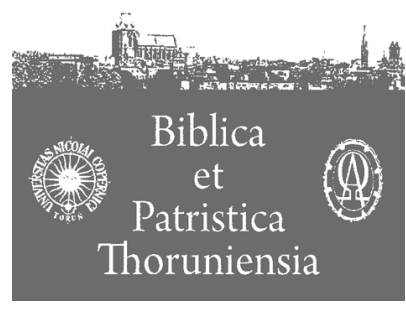

$6(2013) \quad$ ISSN 1689-5150

\title{
Hipokryzja i jej przykłady w Moraliach św. Grzegorza Wielkiego
}

\section{Hypocrisy and its examples in Moralia in Iob of St. Gregory the Great}

Słowa klucze: hipokryzja; złodziej; kłamstwo; św. Grzegorz Wielki; Moralia.

Key words: hypocrisy; thief; a lie; St. Gregory the Great, Moralia in Iob.

Streszczenie. Termin „hipokryzja” jest rzadko używany z powodu jego złej opinii w teologii i życiu codziennym. Grzegorz Wielki w swoim dziele dobrze go tłumaczy i porównuje do złodzieja, który kradnie chwałę sprawiedliwych. Cel życia hipokrytów jest jak senne marzenie, które znika. Hipokryta buduje swoje życie jak pająk swoją sieć, która może zniszczyć wiatr. Radość hipokryty jest krótkotrwała. Chce znać Słowo Boże, lecz nie wcielać je w życie. Zamiast szukać chwały Królestwa Bożego, hipokryta kocha świat i szuka swojej własnej chwały. Grzegorz Wielki łączy ten etap życia z kłamstwem, udawaniem i podwójnym zachowaniem.

\begin{abstract}
The article analyzes the term of hypocrisy, often neglected because of its bad reputation in theology and everyday life. Gregory the Great explains it well in his work and compares it with a thief that steals the glory of the just. The fate of hypocrites is miserable and the aim of their life is like a dream which goes away. A hypocrite constructs his life like a spider constructs its cobweb. It is for sure that the wind can destroy its deed. The joy of the hypocrite is like a point, so short. He wants to know the Word of God but not to put it into practice. Instead of looking for the glory of Kingdom of God, the hypocrite looks for his own glory and he likes the world. The Pope writes that this stage of life is linked with a lie, simulation and double behavior.
\end{abstract}




\section{Wprowadzenie}

Q adany termin, niewdzięczny i odpychający, występuje dość często w obB szernym dziele św. Grzegorza Wielkiego, pt. Moralia, które jest niczym innym jak Komentarzem do Księgi Hioba. Dzieło składa się z 35 ksiąg. W polskiej szacie słownej, w trzech tomach mamy przetłumaczonych 16 ksiąg. Ten wybitny papież opisywał czym jest hipokryzja i nawiązywał do tego terminu przy komentowaniu zdawałoby się odległych od tego terminu zdań, używając różnych jego odmian gramatycznych. Choć jest wiele odmian obłudy w życiu, to w gruncie rzeczy sprowadza go do jednego słowa. Formy mogą być zaskakujące, ale główne idee (kłamstwo, próżność, pycha) i działanie (rodzaj odgrywania komedii) powtarzają się. Praktyki jałmużny, postu i modlitwy służą by dominować nad innymi ${ }^{1}$.

Ze względu na jego pejoratywne konotacje termin ten nie doczekał się szerszego wyjaśnienia nawet we współczesnych opracowaniach. Dla przykładu, nie istnieje on chociażby w Słowniku Wyrazów Obcych, Wydawnictwa PWN z 1991 r. W związku z tym, że się nim szafuje oraz że jest on nadzwyczaj aktualny, bo Ewangelia nigdy się nie starzeje, istnieje potrzeba odwołania się ad fontes, aby zrozumieć jego znaczenie i strzec się tego typu postaw, które od początku były potępiane tak przez Chrystusa jak i przez Ojców Kościoła. Dziś można dołączyć do niego podwójne życie duszy i ciała, nieszczerość, nieuczciwość i przewrotność, konformizm, konwencjonalizm, powierzchowność czy z języka włoskiego perbenizm. Wykłady sprzed XIV wieków nic nie straciły na aktualności, a ich głębia jest ponadczasowa.

\section{Nauczanie papieża z przełomu VI i VII w.}

Omawiany problem rozwija Grzegorz Wielki. Zgłębiając go tym samym precyzuje istotę hipokryzji. Czyni to pisząc obszerny komentarz do poszczególnych zdań Księgi Hioba. Na jego podstawie można wydobywać wiele pięknych myśli, wyrażeń i komentować je poza kontekstem. Tymczasem należy zacząć od dłuższej wypowiedzi na bazie cytatu Elifaza, który chciał zarzucić taką postawę Hiobowi. Podstawą jest werset „Tygrys zginął ponieważ nie miał łupu” (por. Hi 4,11). Komentarz do niego jest następujący:

Każdy obłudnik, chociaż chce być postrzegany jako prawy, nie we wszystkim wydaje się czysty. Gdy przybiera w swej obłudzie niektóre cnoty, a w ukryciu ule-

1 Por. M. Dubost (red.), Théo, L’encyklopédie catholique pour tous, Paris 1989, s. 829. 
ga wadom, to niektóre ukryte wady niespodziewanie wychodza na wierzch. Pokazawszy się, ujawniaja jakby pstrokata skórę powierzchownego udawania. Tak więc często bywa zdumiewajace, dlaczego człowiek, który wydaje się jaśnieć takimi cnotami, plami się również tak nagannymi czynami. Lecz bez wątpienia każdy obłudnik jest tygrysem, bo, gdy udając przybiera czysta barwę, zostanie ona upstrzona czarnymi plamami wad. Nieraz ktoś chlubiac się nieskazitelna czystościa, plami się brudem chciwości. Często, gdy ktoś odznacza się cnotą hojności, jest skalany skaza rozwiązłości. Często, gdy ktoś jest przybrany powabami czystości i hojności, oszpeca się - pod pozorem gorliwej dbałości o sprawiedliwość srogim okrucieństwem. Często ktoś przybiera piękne pozory hojności, czystości, miłosierdzia, lecz jest naznaczony czarnymi plamami pychy. A gdy ujawnia się grzechy, wtedy hipokryta nie ukazuje już czystego oblicza i (tak jak tygrys) w żaden sposób nie może mieć jednakowej barwy. Ów tygrys oczywiście porywa łup, ponieważ przywłaszcza sobie chwałę ludzkiej przychylności. Kto bowiem chlubi się przywłaszczona chwała, ten jakby sycit się łupem. Słusznie zatem chwała hipokrytów nazwana została łupem. Z łupem mamy do czynienia wtedy, gdy przemoca zabiera się cudze rzeczy. Zatem każdy obłudnik, udając sprawiedliwe życie, przywłaszcza sobie chwałe sprawiedliwych, i oczywiście to, co bierze, jest cudza rzecza $a^{2}$.

Skoro tekst jest komentarzem do Księgi Hioba nie wymaga wyjaśnienia, a dołączenie kolejnych jego fragmentów przynosi obraz obłudnika, który się składa niczym w puzzle. Gdy na przykład jest mowa o sitowiu i końcu wszystkich, którzy zapominają o Bogu i że nadzieje obłudnika przepadną (por. Hi 8,12-13), Grzegorz Wielki postanowił użyć obrazu wraz z praktycznym zastosowaniem: Mianem sitowia i pałki wodnej oznaczono tu życie obłudnika: wegetację, która nie przynosi pożytecznego owocu zaspokajającego ludzkie potrzeby. Pozostaje ono suche wskutek jałowego działania, a tylko pozornie kwitnie świętością. Lecz ani sitowie nie rośnie bez wilgoci, ani szuwary bez wody, bo życie obłudników wprawdzie zostaje nawodnione Boża łaska ku spełnianiu dobrych uczynków, ale szukając publicznych pochwał we wszystkim, co czyni, nie wydaje owocu otrzymanego nawodnienia ${ }^{3}$. W tym fragmencie odczuwalne są echa pelagianizmu. Zakończenie rozważeń skłania do współpracy z łaską Bożą, aby zasłużyć sobie na życie wieczne, będąc kwiatem, owocem, czy ziarnem, który powinien trafić do spichlerza Pana, a nie na spalenie. Rekapitulując, papież przestrzega:

2 Gregorius Magnus, Moralia in Iob, V, 20; w Corpus Christianorum Series Latina 143, 143 A, 143 B, ed. M. Adriaen, Tournhout 1975-1985; Źródła Monastyczne, Kraków 1993- (dalej ŹM) 39, s. 409-410.

3 Ibidem. VIII, 42, w : ŹM 41, s. 211. 
A zatem sitowie ani szuwary nie żyja bez wody, gdyż obłudnicy, rzecz jasna, jedynie $w$ darze od Boga otrzymuja żywotność ku dobrym uczynkom. Ponieważ jednak wykorzystuja ja dla własnej chwały, rosna jak zielone rośliny dzięki wodzie, ale na próżno ${ }^{4}$.

$\mathrm{W}$ księdze ósmej jest wiele tego typu porównań. Inni Ojcowie też z nich korzystali. Dla przykładu często rozbrzmiewało zdanie: Sitowie $w$ rozkwicie to obłudnik u szczytu sławy (Scirpus in flore est hypocrita in laude) ${ }^{5}$. Cezary z Arles przyrównywał pijaków do bagna ${ }^{6}$, ale Grzegorz z sitowia i szuwarów uczynił przedmiot głębszej refleksji. Szuwary zaś o ostro zakończonych liściach nie sq zrywane ręka, gdyż obłudnik, jako drażliwy, zarozumiały i zuchwały, nie życzy sobie być karconym za swoja nieprawość. Będac w rozkwicie, rani rękę zrywajacego, gdyż obłudnik cieszacy się sława natychmiast surowo piętnuje życie tego, kto go skrytykowat, aby nikt już nie ośmielił się wystapić z przyganą. Dąży bowiem nie do tego, żeby być świętym, lecz by uchodzić za świętego, a kiedy przypadkiem doczeka się nagany, jest tak, jakby odcinano go od chwały i uznania ${ }^{7}$.

Refleksja powyższa sprowadzała się do zdania z Księgi Przysłów: „Nie krytykuj szydercy, żeby cię nie znienawidził" (Prz 9,8). Wyprowadzona została ze zdania o sitowiu, że „Gdy jeszcze kwitnie nie zrywa go żadna ręka, a usycha wcześniej niż wszystkie inne trawy" (Hi 8,12). Dalej następuje kolejne porównanie: Taka trawa schnie nawet jeszcze nie wyrwana, ponieważ obłudnik trwa jeszcze w życiu doczesnym, a już traci dzieła swej świętości niby pozory żywotności $i^{8}$.

Tak jak sława obłudnika do której dąży, ulatnia się z każdą chwilą, tak jest też z jego losem. W istocie przepada razem $\mathrm{z}$ tym, co ukochał.

Czegóż bowiem spodziewa się obłudnik we wszystkich swoich dziełach, jeśli nie zaszczytnego szacunku, chwalebnej sławy, tego, aby lepsi się go bali, a wszyscy nazywali świętym? Ale nadzieja obłudnika nie może być trwała, ponieważ nie szukając wieczności, traci on wszystko, co ma. Intencja jego ducha wcale nie zmierza konsekwentnie ku owej chwale, która posiada się bez końca. Obłudnik

4 Ibidem, s. 212.

5 Gregorius Magnus VIII, 42; ŹM 41, s. 212.

6 Caesarius Arelatensis, Sermo 46, 2; w: Ojcowie Żywi 17, s. 291: Wszyscy pijacy są niczym bagna. Wasze miłości wiedzą, co rodzi się na bagnach. To, co tam się rodzi, nie przynosi żadnego "pożytecznego» owocu. Rodzą się tam węże, pijawki, żaby oraz różne rodzaje robactwa, które raczej wstręt mogą powodować, niż przynosić coś nadającego się do spożycia. Wydaje się, że z traw i drzew rosnących na bagnach lub na ich brzegach nie ma żadnego pożytku. Nadają się tylko do spalenia w ogniu. Zobaczcie, że to, co rodzi się z pijaństwa, przeznaczone jest do ognia.

7 Gregorius Magnus VIII, 42; ŹM 41, s. 212.

8 Ibidem, s. 215. 
bowiem, pragnac chwilowego poklasku, wraz z osiagnięciem celu zaprzepaszcza rezultaty swoich wysitków ${ }^{9}$.

Skoro obłudnik (hypocrita) nie szuka wieczności, to jest on człowiekiem niewierzącym. Nie raz mówiono już o nich, że szukają tylko chwały doczesnej. Los ich opisywany przez Grzegorza wzbudza grozę. Jego komentarz do słów z Księgi Hioba: Odsłonięta będzie odrośl domu jego, usunięty będzie w dniu gniewu Bożego $(20,28)$ jest następujący: Odrośl jego domu będzie odsłonięta, gdy zostanie ukazane wszelkie zło, które zrodziło się w jego sumieniu. Na razie bowiem odrośl domu obłudnika (germen domus hypocritae) pozostaje tajna, bo jego uczynki pozornie wydaja się dobre (bona imagine apparet eius operatio), a intencja pozostaje $w$ ukryciu (latet intentio). Czyni on co innego, a do czego innego dąży. Gdy jednak przybędzie Sędzia, sumienie każdego zostanie wezwane na świadectwo, bo napisano: «Gdy myśli będa oskarżać lub też bronić» $(R z 2,15)$. Wówczas odsłoni się odrośl domu obłudnika, bo zostaną odkryte przewrotne myśli jego umysłu. A w dniu sądu będzie usunięty, bo gdy objawi się gniew Sędziego, zostanie wydany karzacym płomieniom i zabrany sprzed Jego oblicza. Nie chciat on bowiem myśleć o rzeczach najwyższych, gdy żył, toteż przygnieciony ciężarem swych grzechów, spada sprzed oblicza Sędziego w otchłań męczarni. Teraz zaś Sędzia i widzi, i toleruje grzesznika, i oczekuje na nawrócenie wszystkich, dopóki trwa dzień cierpliwości, a nie nastał jeszcze dzień sądu. Lecz podczas tego dnia cierpliwości obłudnik pozostaje niewzruszony, bo popełnia liczne niegodziwości $i$ nie powściagaja go żadne kary. Lecz $w$ dniu gniewu będzie usunięty, bo zabrany $w$ czas pomsty na męki, odłaczony zostanie od oblicza Przedwiecznego Sędziego ${ }^{10}$.

Ileż podobnych tekstów można zebrać, aby odmalować obraz obłudnika. O nich powiedział jeszcze, że: Nawet obłudnicy gromadza dobre dzieła, lecz ich zbiory sa jałowe. Nie dąża oni do tego, aby dzięki temu, co czynia, otrzymać owoc wiecznej nagrody. W oczach ludzkich wydaja się żywotni i kwitnący w swych dziełach, lecz w oczach ukrytego Sędziego okazuja się wyschnięci i jałowi. Często zaś, rozpaleni żarem chciwości, ukazuja ludzkim oczom tym większe swe dzieła, im większe dary chca pozyskać od ludzi ${ }^{11}$.

Zbiory jałowe nasuwają obraz ewangeliczny, aby poprzez dobre uczynki gromadzić sobie skarby w niebie (por. Mt 6,19). Zabiegi obłudników, ich nawet dobre przedsięwzięcia, ale robione po to, aby się pokazać, aby coś „ugrać”, aby

9 Ibidem. Pierwsza część tej wypowiedzi może uchodzić za definicję: Quid enim cunctis suis operibus hypocrita sperat nisi honoris reverentiam, gloriam laudis, a melioribus metui, sanctus ab omnibus vocari?

10 Gregorius Magnus, XV, 32; ŹM 44, s. 255-256.

11 Gregorius Magnus XII, 53; ŹM 44, s. 114. 
iść naprzód w zdobywaniu pochwał i dorabianiu się są bezowocne. Przykre jest to, że oni nie czynią dobrych dzieł sub specie aeternitatis, czyli w odniesieniu do wieczności. Ich życie - jak wyraża to papież - już jest pustką i nic nie wnosi do wieczności.

Grzegorz Wielki nie szczędził różnego rodzaju spostrzeżeń pod adresem hipokrytów. Ich pewność porównywał do pajęczyny misteryjnie utkanej, $\mathrm{z}$ wielkim trudem, co niszczy powiew wiatru. Wszystko nad czym się trudza dla zdobycia sławy, rozproszy wiatr śmiertelnego życia ${ }^{12}$.

Swiat obłudnika to swoista mrzonka, która niczym po przebudzeniu znika. W dłuższej wypowiedzi tak to ujmuje: Czymże jest życie obłudnika, jeśli nie jakaś wizją wyobraźni, która przedstawia w pozornej postaci to, czego nie ma naprawdę? Stusznie też porównane zostało do snu, bo wszelka cześć i chwała, zaledwie zostaja przezeń osiagnięte, zostaja utracone. Często bowiem w nocnych widziadłach wielu biedaków zachwyca się tym, że stali się bogaci; widzą oddawana im cześć, mnóstwo hołdowników, piękne szaty; spostrzegaja, że maja w bród jedzenia, cieszą się, że wyszli z biedy, która z jękiem znosili. Lecz gdy się nagle zbudza, odkrywaja, jak fałszywe było to, czym się cieszyli. Żałuja, że się przebudzili, bo na jawie sa naprawdę ubodzy. Tak też umysły obłudników co innego czynia, a co innego pokazuja ludziom, więc otrzymuja pochwały za demonstracyjna świętość $i$ wynoszeni sq $w$ ludzkiej opinii ponad wielu lepszych. Gdy w swym wnętrzu, w myśli, pysznia się w milczeniu, uważaja, że w oczach Boga sa tacy sami, jakimi ku ich radości postrzegali ich ludzie. Dlatego nawet zarozumiale przypuszczaja, że otrzymają nagrodę życia wiecznego, a ponieważ tutaj ciesza się ludzkimi względami, bynajmniej nie wątpią, że również tam znajdą spoczynek. A $\dot{z}$ tu nagle zaskakuje ich nieznana dotad chwila powołania. Gdy zamykają oczy cielesne, otwieraja duchowe, a gdy zaraz maja otrzymać w udziale wieczne kary, wtedy widza, że w swej cnotliwej opinii byli jakby bogaczami we śnie. Stusznie więc mówi się o tym obłudniku: przeminie jak nocne widziadło (zob. Hi 20, 8). To bowiem, że przez chwile widzi się bogatym w ludzki szacunek, pochodzi z pozoru i wyobraźni, a nie z solidnej cnoty. A gdy jego umysł budzi się wraz ze śmiercia ciała, bez wątpienia poznaje, że śnił widząc się otoczonym ludzkimi względami ${ }^{13}$.

Przykre jest, jak widać z powyższego fragmentu, jego życie. Godne jest nie tyle litości, co uporządkowania, bowiem jego duchowość i pobożność są wymuszone. Papież gdy omawiał IV Stację Drogi krzyżowej Chrystusa pozwolił sobie na taką krótką refleksję: Co bowiem czynimy pod przymusem tego nie wykonujemy z gorliwej miłości. A zatem dźwiganie krzyża Jezusa $z$ przymusu oznacza znoszenie udręk postu $z$ inna, niż należałoby, intencja. A czy ten, kto

\footnotetext{
12 Gregorius Magnus VIII, 44; ŹM 41, s. 218.

13 Gregorius Magnus XV, 6; ŹM 44, s. 229-230.
} 
rzekomo z nakazu Pańskiego ujarzmia ciało, a jednak nie kocha duchowej ojczyzny, nie dźwiga krzyża Jezusa pod przymusem? Dlatego ów Szymon niesie krzyż, ale wcale nie umiera, gdyż każdy obłudnik wprawdzie umartwia ciało postami, niemniej jednak żyje dla świata, miłując chwałę ${ }^{14}$.

Grzegorz I Wielki wyśmiewał przewrotność, bezowocność, nieproduktywność postów i przedsięwzięć obłudników. Obłudnicy czynia bowiem wiele zła ukradkiem, niektóre zaś dobre uczynki - publicznie ${ }^{15}$. Zło dominuje, podczas gdy dobre uczynki u nich mają stanowić rodzaj zapory, sukni, w którą oni przywdziewają. Teksty o tych niegodziwcach się uzupełniają. Komplementarnym nauczaniem jest następujący fragment: Niegodziwcami nazwani zostali obłudnicy, którzy w zły sposób czyniq dobro, a wszystkiego, co stuszne, dokonuja dla pochwały. [...] Obłudnicy moga też z pewnościa zostać nazwani niegodziwcami dlatego, że okazuja życzliwość względem bliźnich, a ukrywaja podstępy własnej nieprawości ${ }^{16}$.

Teksty zaczerpnięte z księgi Hioba wymagały dobrej obserwacji, żeby dojść do konkretnych wniosków. Mógł sobie pozwolić na nie tylko teolog uznany przez Kościół jako Wielki Doktor Kościoła: powinniśmy teraz rozważyć, czemu obłudnik ma zmarnieć jak winnica w porze pierwszego kwitnienia i jak drzewo oliwne tracace kwiaty. Kiedy kwitnąca winnice z powodu nieodpowiedniej pogody zwarzy nadmierny mróz, zaraz wysycha jej wilgotna zieloność. Lecz sa tacy, którzy szli po ścieżkach upadku, a potem chca podażać drogami świętości. Zanim jednak, jak już powiedzieliśmy, umocnia się ich dobre pragnienia, pociagnie ich jakaś pomyślność życia doczesnego i wplacze w sprawy zewnętrzne. Odciaga ich umysł od wewnętrznego żaru miłości, jakby wyniszczajac go chłodem i zabija to wszystko, co - jak się wydawało - wydało kwiat cnót ${ }^{17}$.

W życiu tych, którzy chcą się nawracać i kroczyć drogą świętości, nie ma nic godnego nagany. Wprost przeciwnie jest to postawa ewangeliczna. Zetkną się zapewne autor tych słów z tymi, którzy próbowali jedynie stwarzać pozory nawrócenia. Jeżeli je sprawiali, tak jak i pozory świętości, to też dla własnej korzyści.

Poza tym radość bezbożnych jest krótka. Dowodzi tego poniższy fragment komentarza: Bezbożni, ponieważ kochaja życie doczesne, bez wątpienia w swej pysze chca w nim osiagnać chwałe. Wywyższaja się pod wpływem pochlebnej mowy, bo nie tyle chca być dobrzy, co być tak nazywani. Gdy uzyskuja tę chwate, oczywiście uważaja, że będzie ona długotrwała, lecz gdy ją traca, zaczynaja rozu-

17 Gregorius Magnus XII, 44; ŹM 44, s. 112. 
mieć, że była krótka. A gdy nadchodzi ich kres, okazuje się, że to, co kochali, było niczym. Dlatego słusznie powiada się przeciwko tym właśnie bezbożnym: Wiem to od początku, odkąd człowiek został osadzony na ziemi, że chwała bezbożnych jest krótka. Słusznie też tam dodano: a radość obłudnika niczym punkcik ${ }^{18}$.

To stwierdzenie zostało powtórzone jeszcze w tym samym rozdziale dwa razy. Czyli ich radość jest na wzór kropki. Inaczej mówiąc jest tak mała jak chwila, moment ${ }^{19}$.

Do lapidarnych stwierdzeń Grzegorza należą między innymi: Obłudnik chce znać Słowo Boże, ale nie chce wypetniać. Chce mówić, ale nie żyć zgodnie $z$ nauka ${ }^{20}$. W tej samej księdze zapisał także: żaden obłudnik nie kocha ani Boga, ani bliźniego, gdyż szuka przemijajacej chwały świata. [...] Obłudnik, szukając doczesnych zysków, lekceważy przyszłe dary. Nie mając wiary, nie widzi swym umysłem zdrojów rzeki, bo Wiara jest [...] dowodem rzeczy niewidzialnych ( $\mathrm{Hbr}$ 11,1). Obłudnik, trwajac przy rzeczach widzialnych, lekceważy nadzieje na niewidzialne ${ }^{21}$.

Inne zdanie, które może stanowić przedmiot medytacji brzmi: Zło jest słodkie w ustach obłudnika, bo nieprawość sprawia przyjemność jego umysło$w i^{22}$. Poza tymi zdaniami można przytaczać kolejne, które są pełne pesymizmu i wzbudzają trwogę: Umyst obłudnika nigdy nie jest wolny od złej myśli (mens hypocritae numquam vacat a malitiae cogitatione $)^{23}$.

Grzegorz Wielki zdawał sobie sprawę, że Kościół utrzymuje na łonie wiary wielu nieprawych, którzy zawsze są w stanie poprzez niegodziwą obłudę wyprzeć się nauki, którą zdobyli. Są nawet w stanie prześladować Kościół. Gdy jest pokój udają pobożnych, bo to przynosi im korzyści. Toteż gdy w Księdze Hioba pada zdanie: „A zmarszczki moje świadczą przeciw mnie (Hi 16,8) bez wahania klaruje: Cóż określa się przez zmarszczki, jeśli nie obłudę? Zmarszczkami Kościoła sa wszyscy ci, którzy żyja w nim dwulicowo - którzy głosza wiarę słowami, czynami zaś się jej zapierają ${ }^{24}$. Kościół jak naucza Apostoł Narodów nie powinien mieć skazy ani zmarszczki (zob. Ef 5,27).

18 Gregorius Magnus XV, 3; ŹM 44, s. 227.

19 Tamże: gaudium hypocritae ad instar puncti.

20 Gregorius Magnus XV, 14; ŹM 44, s. 236.

21 Gregorius Magnus XV, 16; ŹM 44, s. 240.

22 Gregorius Magnus XV, 11; ŹM 44, s. 233: In ore hypocritae malum dulce est, quia ei est iniquitas suauis in mente.

23 Gregorius Magnus XII, 54; ŹM 44, s. 115.

24 Gregorius Magnus XIII, 8; ŹM 44, s. 123-124. 


\section{Wnioski i zakończenie}

„Dobry Bóg nie napisał, abyśmy byli miodem ziemi, ale solą” - te słowa często są cytowane, a pochodzą od ich pomysłodawcy jakim był Georges Bernanos $^{25}$. Powiedzenie to przestrzega, aby nie być śliskim jak śledź czy słodkim jak miód, aby lawirować, przymilać się do innych, reprezentować postawę ugodową, „światowość duchową" ${ }^{26}$ i omijać trudne problemy życiowe, podczas gdy trzeba być jak sól. Sól posypana zwłaszcza na ranę szczypie, wywołuje krzyk, nienawiść, może skończyć się agresją. Jednakże do zupy nie potrzeba łopaty soli, wystarczy szczypta. Cum grano salis (Ze szczyptą soli) - mówi stare powiedzenie - wszystko staje się smaczne i dobre, w przeciwnym razie bez soli jest nijakie. Sól konserwuje, zachowuje na długie lata, zatem niniejszy artykuł niech przyczynia się do realizacji twardej postawy, do demaskowania obłudy, której należy się wstydzić przed Bogiem i ludźmi, a realizować Chrystusową prawdę, która mówi: „Wy jesteście solą dla ziemi” (Mt 5,13).

Hipokryzja to stan, zachowanie, które polega na udawaniu, kłamstwie ${ }^{27}$, stwarzaniu pozorów, że się posiada cnoty i żyje zgodnie z religijnymi przekonaniami, zasadami innych, a w gruncie rzeczy jest odwrotnie. Hipokryci nigdy nie założyli religii. Zadowalali się dyskredytacją szczerze wierzących. Pozbawiali ich owoców płynących z właściwych postaw. Hipokryzja pozwala na oszukanie innych, to swoisty rodzaj kłamstwa. Hipokryta często coś ściemnia albo rozjaśnia, ubarwia, nie nazwie prawdy po imieniu. Najczęściej wyrażają hipokryzję słowa, ale już nie czyny, choć może być i tak, że czynami społecznymi, datkami na kościół, ktoś przykryje lichwę, czy oszustwa podatkowe. Hipokryzja to też pyszna pokora, brak prawdziwej cnoty humilitas ${ }^{28}$.

Przeanalizowany został termin hipokryzja, quo ad verbum, jednakże można się go także doszukiwać w nauczaniu współczesnych papieży. Jan Paweł II w adhortacji apostolskiej Ecclesia in Europa mówił o wijącej się „milczącej apo-

25 Zob. M.M. Zanotti-Sorkine, Au diable le tiédeur suivi de Petit traité de l'essentiel, Paris 2012, s. 9.

26 Zob. J.M. Bergoglio, Francesco, Guarire dalla corruzione, Bologna 2013, s. 40.

27 Por. Petrus Chrysologus, Sermo 9, 5; Corpus Christianorum Series Latina, t. 24; s. 67: Hypocrisis, dolus, simulatio, fraus, mendacium, elatio, tumor, iactantia insistunt nobis et inminent in sinistris.

28 Gregorius Magnus VII, 35; ŹM 41, s. 132: Superbia quippe odium generat, humilitas amorem. 
stazji”29. Kard. Józef Ratzinger zanim został papieżem, podczas nabożeństwa Drogi Krzyżowej w Wielki Piątek 2005 r., powiedział przy IX stacji: „Ileż brudu jest w Kościele, a także wśród duchownych, którzy powinni całkowicie należeć do Niego! Ileż pychy i samouwielbienia!"30.

Miłość, prostota i uczciwość to cechy, które pomagają ją zwalczać. Z hipokryzją zmaga się człowiek od zarania dziejów, praktycznie od upadku rodziców i przewrotnego pytania Diabła: Czy rzeczywiście Bóg powiedział... (por. Rdz $3,1)$. To tak jakby podważyć jakąkolwiek wypowiedź normatywną i zapytać czy rzeczywiście tak jest, albo czy tak być musi, to wywrócenie ustalonego porządku rzeczy.

W kontekście wielu refleksji Grzegorza Wielkiego ostrzeżeniem niech będzie zdanie z Listu do Hebrajczyków, choć literalnie badany termin tu nie występuje: Uważajcie, bracia, aby nie było $w$ kimś $z$ was przewrotnego serca niewiary, której skutkiem jest odstąienie od Boga żywego, lecz zachęcajcie się wzajemnie każdego dnia, póki trwa to, co dziś się zwie, aby żaden z was nie ulegt zatwardziałości przez oszustwo grzechu (Hbr 3,12-13).

29 Jan Paweł II, Adhortacja Apostolska Ecclesia in Europa, Kościół w Europie, Poznań 2003, pkt 9, s. 13-14: Jedną z przyczyn gaśnięcia nadziei jest dążenie do narzucenia antropologii bez Boga i bez Chrystusa. Taki typ myślenia doprowadził do tego, że uważa się człowieka za «absolutne centrum rzeczywistości, każąc mu w ten sposób wbrew naturze rzeczy zająć miejsce Boga, zapominając o tym, że to nie człowiek czyni Boga, ale Bóg czyni człowieka. Zapomnienie o Bogu doprowadziło do porzucenia człowieka» i dlatego «nie należy się dziwić, jeśli w tym kontekście otworzyła się rozległa przestrzeń dla swobodnego rozwoju nihilizmu na polu filozofii, relatywizmu na polu teorii poznania i moralności, pragmatyzmu i nawet cynicznego hedonizmu w strukturze życia codziennego». Europejska kultura sprawia wrażenie «milczącej apostazji» człowieka sytego, który żyje tak, jakby Bóg nie istniał. W takim kontekście konkretyzują się próby - pojawiające się również ostatnio - by przedstawiać kulturę europejską z pominięciem wkładu chrześcijaństwa, który wywarł wpływ na jej historyczny rozwój i jej rozprzestrzenienie się po całym świecie. Jesteśmy świadkami narodzin nowej kultury, pozostającej w znacznej mierze pod wpływem środków masowego przekazu, której cechy charakterystyczne i treści często sprzeczne są z Ewangelią i z godnością osoby ludzkiej. Do kultury tej należy też coraz bardziej rozpowszechniony agnostycyzm religijny, związany z pogłębiającym się relatywizmem moralnym i prawnym, który jest następstwem zagubienia prawdy o człowieku jako fundamencie niezbywalnych praw każdego. Oznaką gaśnięcia nadziei bywają niepokojące formy tego, co można nazwać «kulturą śmierci».

30 L'Osservatore Romano 5 (2005), s. 42 zawiera tylko wzmiankę o niej, bez tekstów pt.: 25 III Droga Krzyżowa w Koloseum w Wielki Piątek. Witaj, Krzyżu, jedyna nadziejo. Teksty i modlitwy: http://www.opoka.org.pl/biblioteka/W/WR/inne/ratzinger_drogakrzyzowa-or_25032005.html (data dostępu: 22.05.2013 r.) 